\title{
Contactin-Associated Protein 1
}

National Cancer Institute

\section{Source}

National Cancer Institute. Contactin-Associated Protein 1. NCI Thesaurus. Code C25999.

Contactin-associated protein $1(1384 \mathrm{aa}, \sim 156 \mathrm{kDa})$ is encoded by the human CNT NAP1 gene. This protein is involved in neuronal signaling. 